AL-IQTISHOD: Jurnal Pemikiran dan Penelitian Ekonomi Islam

E-ISSN: 2745-85I2 P-ISSN: 2407-6600

Volume 9 Issue 2 Juli 202I | Page: I09-I26

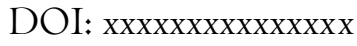

\title{
MAKANAN DAN MINUMAN PRODUK BARAT DALAM PERSPEKTIF HUKUM ISLAM
}

Kholishudin

STAI AL Azhar Menganti, Gresik, Indonesia

kholishudinmuhammad@gmail.com

Shelvyna Rikantasari

UIN Sunan Ampel, Surabaya, Indonesia

shelvyna@gmail.com

Abstract: In the era of globalization and free trade today, it has an impact on increasing food and beverage products both local and imported in the community. Food and beverage products circulating in society do not necessarily provide a sense of security, comfort, serenity and are suitable for consumption by Muslim consumers. Guarantee regarding halal products is carried out in accordance with the principles of protection, justice, legal certainty, accountability and transparency, effectiveness and efficiency as well as professionalism. In this study, using the library research method, namely a literature review in which the researcher conducted a series of studies involving various sources related to the legal status of consuming western food products. The result of this research on western food and beverage products is that everything that is allowed by Islam can be said to be halal. Halalness includes how the product is obtained, processed, and other factors. Anything that can damage the mind, body, and soul is called haram. Halal in the form of food does not contain ingredients or elements that are haram or something that is not permitted for consumption and the processing method is in accordance with Islamic law.

\section{Keywords: Western food products, halal, halal food certification}

Abstrak: Di era globalisasi danperdagangan bebas dewasa ini berdampak pada meningkatnya produk makanan dan minuman baik lokal maupun impor di masyarakat. Produk makanan dan minuman yang beredar di masyarakat belum tentu memberi rasa aman, nyaman, tentram dan layak dikonsumsi oleh konsumen muslim. Jaminan mengenai produk halal dilakukan sesuai dengan asas perlindungan, keadilan, kepastian hukum, akuntabilitas dan transparasi, efektifitas dan efisiensi serta profesionalitas. Dalam penelitian ini menggunakan metode kepustakaan (library riset) yakni kajian literatur dimana peneliti melakukan serangkain kajian yang melibatkan berbagai macam sumber yang terkait dengan hal status hukum mengkonsumsi produk makanan barat. Hasil dari penelitian makanan dan minuman produk barat ini yakni semua hal yang diperbolehkan oleh Islam dapat dikatakan halal. Kehalalan meliputi bagaimana cara produk itu diperoleh, diproses, dan faktor lain. Sesuatu yang dapat merusak pikiran, tubuh, dan jiwa disebut dengan haram. Halal berupa makanan tidak memuat bahan atau unsur haram atau sesuatu yang tidak diizinkan untuk dikonsumsi dan cara pengolahan yang sesuai syariat Islam.

Kata Kunci : Makanan produk barat, hukum mengkonsumsi, sertifikasi makanan halal 



\section{A. Pendahuluan}

Manusia diciptakan sebagai makhluk yang paling sempurna, dikaruniai akal dan pikiran, dapat berkomunikasi, dan berbicara. Kesempurnaan inilah yang membedakannya dengan makhluk lain yang ada di muka bumi ini. Manusia semenjak dahulu memiliki pandangan yang berbeda dalam menilai makanan dan minuman, baik terkait makanan yang diperbolehkan maupun makanan yang dilarang, terutama makanan yang mengandung bahan yang berbahaya.Sementara makanan dan minuman dari tumbuh-tumbuhan tidak banyak diperselisihkan.Islam tidak mengharamkan makanan dan minuman tersebut, kecuali jika makanan tersebut dapat membahayakan kesehatan yang mengkonsumsinya.

Di era globalisasi danperdagangan bebas dewasa ini berdampak pada meningkatnya produk makanan dan minuman baik lokal maupun impor di masyarakat. Produk makanan dan minuman yang beredar di masyarakat belum tentu memberi rasa aman, nyaman, tentram dan layak dikonsumsi oleh konsumen muslim. Karena syariat mewajibkan kepada umat Islam untuk mengkonsumsi makanan dan minuman halal sesuai syariat Islam.

Jaminan mengenai produk halal dilakukan sesuai dengan asas perlindungan, keadilan, kepastian hukum, akuntabilitas dan transparansi, efektifitas dan efisiensi serta profesionalitas.Jaminan penyelenggaraan produk halal bertujuan memberikan kenyamanan, keamanan, keselamatan, dan kepastian ketersediaan produk halal bagi masyarakat dalam mengkonsumsi dan menggunakan produk halal serta meningkatkan nilai tambah bagi pelaku usaha untuk memproduksi produk halal. ${ }^{1}$

Jaminan produk halal menjadi penting mengingat kemajuan ilmu pengetahuan dan teknologi di bidang pangan, obat-obatan, dan kosmetik berkembang pesat. Hal ini berpengaruh secara nyata pada pergeseraan pengelolahan dan pemanfaatan bahan baku untuk makanan, minuman, obat-obatan dan kosmetik serta produk lainnya dari yang semula bersifat sederhana dan alamiyah menjadi pengolahan dan pemanfaatan bahan baku hasil rekayasa ilmu pengetahuan. Pengolahan produk dengan pemanfaatan kemajuan ilmu

${ }^{1}$ Ahmad Miru \& Sutarman, Hukum Perlindungan Konsumen,(Jakarta:Rajagrafindo Persada, 2015), 80.

Volume. 9/No. 2/Juli 202I Al-Iqtishod | 109 
Makanan dan Minuman ...

pengetahuan dan teknologi memungkinkan percampuran antara yang halal dan yang haram baik yang disengaja maupun tidak disengaja.Oleh karena itu, untuk mengetahui kehalalan dan kesucian suatu produk, diperlukan suatu kajian khusus yang membutuhkan pengetahuan multi disiplin, seperti pengetahuan dibidang pangan, kimia, biokimia, biologi, farmasi dan pemahaman tentang syariat. ${ }^{2}$

Salah satu upaya yang dilakukan Negara untuk mewujudkan kesejahteraan sebagai wujud Negara hukum adalah memperhatikan kepentingan masyarakat. Indonesia merupakan salah satu Negara di kawasan Asia Tenggara dengan penduduk muslim terbesar di dunia dalam melaksanakan kehidupan bernegara, yang mempunyai karakteristik yang berbeda dengan Negara lain. Kehidupan bernegara di Indonesia banyak dipengaruhi oleh dogma Islam yang diaktualisasikan dalam kehidupan masyarakat, tanpa mengensampingkan masyarakat non muslim.

Produk impor ini sudah bukan barang langka bagi masyarakat Indonesia, terutama di kota besar seperti Surabaya dan kota-kota lainnya, karena sudah tersedia supermarket yang khusus menyediakan barang impor. Namun jumlah supermarket yang menjual produk impor ini masih sangat terbatas dibandingkan dengan supermarket yang menjual produk lokal. Produk lokal yang dimaksud yakni produk yang dibuat oleh industri di Indonesia.

Produk yang bervariasi mengenai makanan yaitu makanan kemasan dimana ada beberapa tempat terutama kota-kota besar yang menyediakan barang tersebut seperti Hokky, Papaya, Ranch Market, Carrefour / Transmart, Giant dan sebagainya.Produk kemasan yang ada yaitu biscuit, coklat, snack, soft cake, pie, rumput laut dan lainnya.

Dewasa ini masih banyak ditemukan peredaran produk makanan dan minuman baik yang lokal maupun yang impor belum berlabel sertifikat halal atau kecurigaan sertifikat halal yang terdapat pada kemasan makanan dan minuman sehingga menimbulkan keraguan tentang halalnya.Hal ini menunjukkan masih rendahnya kewajiban pelaku usaha untuk mengikuti ketentuan hukum sertifikat halal.

${ }^{2}$ Al Hafidz, Fiqh Kesehatan, (Jakarta: Amzah, 2007) 67.

II0| Al-Iqtishod Volume. 9/No. 2/Juli 202I 


\section{B. Kajian Pustaka}

Semua hal yang diperbolehkan oleh Islam dapat dikatakan halal. Kehalalan meliputi bagaimana cara produk itu diperoleh, diproses, dan faktor lain. Sesuatu yang dapat merusak pikiran, tubuh, dan jiwa disebut dengan haram. Halal berupa makanan tidak memuat bahan atau unsur haram atau sesuatu yang tidak diizinkan untuk dikonsumsi dan cara pengolahan yang sesuai syariat Islam. Halal adalah suatu tindakan yang diperbolehkan dilakukan sesuai dengan syariat.

Dalam syariat Islam, ayat-ayat yang memerintah untuk memakan makanan halal diantaranya ayat 57 dan ayat 172 dari surat al-Baqarah, ayat 8I surat Taha, selain ayat itu landasan hukum produk halal sesuai syariat Islam antara lain juga terdapat dalam QS. Al Baqarah (2): I68 yang artinya:

"Wahai manusia, makanlah dari (makanan) yang halal dan baik yang terdapat di bumi, dan janganlah kamu mengikuti langkah-langkah setan.Sungguh setan musuh yang nyata bagimu."

Makna ayat tersebut menerangkan bahwa Allah menyuruh manusia untuk memakan makanan yang halal dan thayib. Kata halalan berarti halal. Dari kata ini diperoleh arti halalan adalah membolehkan sesuatu. Dalam tafsir departeman agama RI mengatakan bahwa kata halalan diberi kata sifat thayiban artinya makanan yang halal adalah makanan yang berguna bagi tubuh, tidak merusak tidak menjijikkan tidak kedaluarsa dan tidak bertentangan dengan perintah Allah karena tidak diharamkan sehingga kata thayiban menjadi illah alasan dibolehkan sesuatu dari makanan.

Perintah untuk memakan makanan yang halal dan thayib yang senada dengan ayat I68 Al-Baqarah yaitu terdapat dalam ayat 88 Al Maidah dan Al Nahl ayat II4. Nampak jelas Islam sangat memperhatikan konsep dan dasar- dasar dalam memelihara kesehatan .apa yang telah diterangkan Al-Quran berkaitan dengan kesehatan sejalan dengan konsep kedokteran dan ilmu Kesehatan.

” Dalam ayat 3 QS Al-Maidah yang artinya:

"Sesungguhnya Dia hanya mengharamkan atasmu bangkai, darah, daging babi dan daging hewan yang disembelih dengan (menyebut nama) selain Allah. Tetapi barang siapa 
Makanan dan Minuman ...

terpaksa (memakannya) bukan karena menginginkannya dan tidak (pula) melampaui batas, maka tidak dosa baginya, Sesungguhnya Allah Maha Pengampun."

Berdasarkan surat Al Maidah tersebut di atas, Allah memerintahkan kepada orang yang beriman untuk memakan makanan yang halal dan melarang memakan bangkai, darah, daging babi, daging hewan yang disembelih dengan tidak menyebut nama Allah, kecuali jika terpaksa dan tidak melampaui batas. dalam pandangan kedokteran kontemporer makanan yang dilarang Al-Quran termasuk babi karena daging babi yang paling susah dicerna karena banyak mengandung lemak yang dapat menghambat pencernaan sehingga perut merasa berat dann jantungnya berdebar debar.

Makanan- makanan yang telah dilarang dalam Al-Quran seperti termaktub dalam ayat 3 surat Al-Maidah tersebut dapat disimpulkan semua yang dilarang dalam ajaran Islam terkait makanan pasti ada mudharatnya bagi manusia. Penting untuk menjamin makanan yang sehat untuk dikonsumsi mamnusia sehingga untuk menentukan produk makanan dan minuman yang beredar di masyarakat itu harus ada jaminan halal berupa logo sertifikat halal yang dikeluarkan oleh LPPOM MUI pada kemasannya.

Di dalam Undang-undang Nomor 33 Tahun 2014 tentang Jaminan Produk Halal lebih memberi perlindungan dan kepastian hukum bagi konsumen mengkonsumsi produk halal. Lima tahun setelah disahkan undang-undang ini pada semua produk yang beredar di masyarakat wajib mencantumkan sertifikat halal pada kemasannya dan sebaliknya apabila produk terdiri dari bahan yang tidak halal, misalnya babi.

Label halal dapat dicantumkan oleh suatu perusahaan jika perusahaan tersebut sudah memiliki sertifikat halal. Sertifikat halal adalah fatwa tertulis MUI yang menyatakan kehalalan suatu produk sesuai dengan syariat Islam.Sertifikat halal memiliki tujuan memberikan kepastian kehalalan suatu produk, sehingga menenangkan batin yang mengkonsumsi.Selain itu, hal ini berdampak pada peningkatan pendapatan Nasional dikarenakan meningkatnya daya saing. 


\section{Metode Penelitian}

Kholishudin, Shelvyna Rikantasari

Dalam penelitian ini menggunakan metode kepustakaan (library riset) yakni kajian literatur dimana peneliti melakukan serangkain kajian yang melibatkan berbagai macam sumber yang terkait dengan hal status hukum mengkonsumsi produk makanan barat. Sumber-sumber dalam penelitian ini berupa buku, dokumen-dokumen yang terkait fatwafatwa atau keputusan-keputusan yang dikeluarkam oleh Lembaga yang memiliki otoritas dan kapabilitas untuk mengeluarkan keputusan hukum. Di Indonesia seperti MUI, representasi dunia arab al-Lajnah al Daimah lil Buhus al-Ilmiyah di Saudi, Dar al Ifta di Mesir yang telah mengeluarkan keputusan hukum produk makanan Barat. Menghimpun berbagai sumber ini guna menemukan gagasan pendapat hukum dari para ulama terkait tentang produk makanan Barat, dari komunitas ulama level international terdapat kutipandari pendapat hukum fatwa Shaykh Yusuf Qardawi, Wahbah al Zuheyli. Dari proses penghimpnan fatwa yang dilalui ini sehingga dapat disimpulkan sebuah hasil dari tujuan penelitian ini,yaitu untuk mengetahui status hukum makanan produk Barat.

\section{Hasil dan Pembahasan}

\section{Proses Pemberian Sertifikat Halal}

Sebelum berlakunya UU no 33 Tahun 20I4, tanda kehalalan suatu produk berdasarkan sertifikat halal yang dikeluarkan oleh LPPOM MUI.Sertifikat halal adalah surat keterangan yang dikeluarkan oleh MUI Pusat atau Propinsi tentang halalnya suatu produk makanan, minuman, obat-obatan dan kosmetika yang diproduksi oleh suatu perusahaan setelah diteliti dan dinyatakan oleh LPPOM MUI. ${ }^{3}$

Pelaku usaha sebelum mengajukan sertifikat halal harus mempersiapkan system jaminan halal yang merujuk kepada Buku Panduan Penyusunan system jaminan halal yang dikeluarkan oleh LP-POM MUI.LPPOM MUI mengangkat seorang atau Tim Auditor halal internal yang

\footnotetext{
${ }^{3}$ Jurnal LPPOM MUI
}

Volume. 9/No. 2/Juli 202I Al-Iqtishod| II3 
Makanan dan Minuman ...

bertanggung jawab dalam menjamin pelaksanaan produk halal. Menandatangani kesediaan secara mendadak tanpa pemberitahuan sebelumnya oleh LPPOM MUI.Serta membuat laporan berkala setiap 6 bulan tentang pelaksanaan Sistem Jaminan Halal.

Produsen mengajukan permohonan sertifikat halal ke sekretariat LPPOM MUI dengan mengisi formulir, mendaftarkan seluruh produk yang diproduksi termasuk lokasi produksi, pabrik pengemasan dan tempat makan, bagi restoran dan catering mendaftarkan seluruh menu yang dijual, gerai, dapur serta gudang. Bagi rumah potong hewan produsen harus mendaftarkan seluruh tempat penyembelihan.

Setiap pemohon yang mengajukan sertifikat halal bagi produknya, harus mengisi borang tersebut yang berisi informasi tentang data perusahaan, jenis, dan nama produk serta bahan-bahan yang digunakan. Borang yang sudah diisi beserta dokumen pendukungnya dikembalikan ke sekretariat.LPPOM MUI memeriksa kelengkapannya dan bila belum memadai perusahaan harus melengkapi sesuai dengan ketentuan. LPPOM MUI melakukan audit tim auditor melakukan pemeriksaan/audit ke lokasi produsen dan pada saat audit, perusahaan harus dalam keadaan memproduksi produk yang disertifikasi.

Hasil pemeriksaan/audit dan hasil laboraturium (bila diperlukan) di evaluasi dalam rapat auditor LPPOM MUI. Hasil audit yang belum memenuhi persyaratan diberitahukan kepada perusahaan. Jika telah memenuhi persyaratan, auditor akan membuat laporan hasil audit guna diajukan pada siding Komisi Fatwa MUI. Sidang Komisi Fatwa MUI dapat menolak hasil audit, jika dianggap belum memenuhi semua persyaratan dan hasilnya akan disampaikan kepada produsen pemohon sertifikasi halal. Sertifikat halal dikeluarkan oleh MUI setelah status kehalalanya oleh Komisi Fatwa MUI.Sertifikat halal berlaku selama 2 tahun sejak tanggal penetapan fatwa. 


\section{Fatwa Mengenai Makanan}

Dalam hal makanan ini ada empat fatwa yang berkaitan dengan makanan. Semua fatwa itu adalah mengenai status hukum dari penyembelihan hewan dengan alat teknologi atau mesin, mengenai hewan yang dijual dalam keadaan sudah disembelih, daging yang diawetkan dan daging yang dijual oleh non muslim. Fatwa tersebut yakni :

a. Menyembelih hewan dengan mesin

Seiring pesatnya pertumbuhan dalam segala aspek kehidupan termasuk pertumbuhan jumplah penduduk yang mengakibatkan meningkatnya kebutuhan masyarakat termasuk konsumsi terhadap daging, lebih lebih ketika saat momen tertentu seperti hari-hari besar serta permintaan pemasokan industri. yang membutuhkan daging skala besar untuk konsumsi. Faktor penyediaan daging dalam skala besar untuk memperolehnya perlu langkah efesiensi dalam hal pengolahan dan penyembelihan. Salah satu solusi adalah dengan melakukan stunning yaitu tindakan pelemahan atau upaya pemingsanan terhadap hewan sehinggga mudah atau cepat untuk disembelih. ${ }^{4}$

Dalm perspektif Majelis ulama Indonesia dalam fatwa nomor 12 tahun 2009 tentang stunning boleh dilakukan dengan beberapa ketentuan. Pertamastunning hanya menyebabkan pingsang dan lemah sementara stunning yang dilakukan pada hewan tersebut tidak mengantarkan kematian, kedua,stunning bertujuan mempermudah penyembelihan, proses penyembelihan tetap dilakukan dengan cara memotong hulkum (tenggorokan), mari" kerongkongan dan pembuluh darah leher. Ketiga,pelemahan, pemingsangan bukan bertujuan menyiksa. Keempat, penggunaan alat penyembelihan harus dipisahkan atau tidak bersamaan

\footnotetext{
${ }^{4}$ Hasbi Umar, Nalar Fiqh Kontemporer (Ciputat: Gaung Persada, 2007), 43.
}

Volume. 9/No. 2/Juli 202I Al-Iqtishod| II5 
Makanan dan Minuman ...

dengan hewan non halal. Pendapat MUI juga senada apa yang dikemukakan oleh imam besar masjid Istiqlal KH Ali Mustafa Ya'qub ${ }^{5}$, kreteria halal haram untuk pangan obat dan kosmetika menurut al-Quran dan Hadis.

Dalam komunitas ulama international yang membolehkan proses stunning dikemukakan oleh Shaykh Wahbah al Zuheili dalam salah satu karyanya al-Fiqh al-Islami wa Adilatuhu mengatakan tidak ada halangan untuk melakukan stunning upaya pelemahan terhadap gerakan hewan yang akan disembelih tanpa ada penyiksaan.

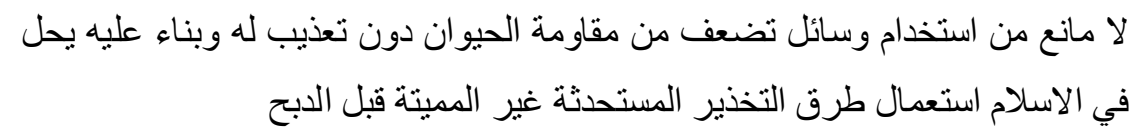

" Tidak ada halangan untuk menggunakan alat yang memperlemah gerakan hewan tanpa ada tujuan penyiksaan terhadapnya atas dasar itu Islam membolehkan menggunajkan alat modern dalam penyembelihan yang tidak menimbulkan kematian sebelum disembelih. ${ }^{6}$

MUI dalam merespon masalah stunning mengeluarkan fatwa yang menyatakan bahwa daging yang disembelih dengan mesin itu halal dimakan jika memenuhi kreteria empath hal yang telah ditentukan dalam keputusan MUI. Selanjutnya fatwa itu mengatakan bahwa cara yang demikian itu lebih mendekati ajaran Nabi daripada cara yang tradisional dalam hal mengurangi penderitaan hewan-hewan yang dipotong. ${ }^{7}$

Meskipun dalam fatwa itu disebutkan persyaratan mengucapkan bismillah dan soal pekerja muslim yang melakukan penyembelihan, sebagai syarat sahnya penyembelihan itu, namun demikian apakah semua perusahaan yang menangani hal itu melaksanakan seperti apa yang disebutkan dalam fatwa tersebut? Jadi, dapat dikatakan bahwa fakta tersebut adalah sah dan

\footnotetext{
${ }^{5}$ Ali Mustafa Ya'kub, Kreteria Halal Haram Pangan Obat dan Kosemetika menurut al-Qur'an dan Hadis (Jakarta: Pustaka Firdaus, 20I4), 65.

${ }^{6}$ Wahbah al-Zuhayli, al-Fiqh al-Islami wa Adllatuh Juz 4 (Lebanon:Dar al-Fikr, 2008),800.

${ }^{7}$ Mui.or.id
} 
berlaku hanya bagi perusahaan yang mengambil pekerja Islam untuk penyembelihan hewan, dengan cara dan peraturan diatas. Selanjutnya, fatwa itu tidak berlaku bagi perusahaan penyembelihan hewan dengan cara dan peraturan penyembelihan lain, yang mungkin menggunakan tenaga kerja orang-orang bukan Islam.

b. Daging hewan yang dijual dalam keadaan sudah disembelih

Fatwa ini dikeluarkan sebagai jawaban atas pertanyaan yang disampaikan kepada Majelis Ulama. Dalam pertanyaan itu disebutkan: Bagaimana hukum memakan daging dalam keadaan sudah disembelih (daging bungkusan seperti cornet beef). Atas pertanyaan tersebut, Komisi Fatwa MUI mengeluarkan fatwa bahwa daging hewan yang sudah disembelih dan diketahui asalnya adalah halal dimakan.

Selanjutnya, fatwa itu menyebutkan bahwa, apabila hewan yang dijual dalam kondisi keadaan sudah disembelih, maka hendaknya diketahui asalusul penyembelihannya sekalipun melalui berita (dari orang) yang dapat dipercaya. Apabila sudah diketahui bahwa hewan itu disembelih orang Islam, seperti daging hewan yang disembelih oleh di tempat pemotongan resmi di negeri Islam, atau menurut berita dari orang yang bisa dipercaya, maka hukum memakannya halal.Tetapi apabila tidak diketahui siapa yang menyembelihnya, sementara yang menjual daging tersebut adalah musyrik, maka hukumnya haram. ${ }^{8}$

c. Makanan yang menggunakan bahan pengawet (cornet beef)

Saat ini, banyak jenis makanan yang menggunakan bahan pengawet agar selalu tahan lama sehingga dapat di ekspor ke luar negeri.Dari segi kebersihan dan kesehatan, makanan tersebut sudah tentu dapat dipertanggung jawabkan. Namun, yang perlu dipersoalkan dari bahan apa ia

${ }^{8}$ LP POM MUI Keputusan tentang Penyedap rasa atau Glutamate pada tanggal I6 Desember 2000.

Volume. 9/No. 2/Juli 202I A1-Iqtishod|II7 
Makanan dan Minuman ...

dibuat. Melihat realita ini MUI mengadakan kajian yang berkaitan dengan status hukum memakan makanan yang menggunakan bahan pengawet tersebut. Dari hasil kajian itu, MUI mengeluarkan sebuah fatwa yang menyatakan bahwa: apabila makanan tersebut menggunakan bahan-bahan pengawet dari bahan sayur-sayuran, buah-buahan ataupun terbuat dari ikan maka ia halal dimakan, karena ia berasal dari sumber yang halal, kecuali bahan tersebut dicampuri dengan barang yang najis maka hukumnya haram.

Adapun daging kemasan seperti cornet beef selain ikan maka perlu diteliti terlebih dahulu. Sekiranya diketahui daging itu berasal dari hewan yang diharamkan, atau hewan yang halal tetapi diolah di Negara non-Islam dan penyembelihannya tidak dilakukan oleh orang Islam atau penyembelihannya tidak dilakukan berdasarkan syariat, maka hukumnya adalah haram. Untuk mengetahui hal tersebut dapat diteliti berdasarkan keterangan atau label (merk) yang ada pada tempat atau kemasannya, misalnya cornet beef (daging yang diawetkan). Seiring dengan fatwa ini, Majelis Ulama memutuskan agar semua produk makanan kemasan, harus memberi label halal bagi orang Islam. ${ }^{9}$

d. Makanan yang dijual oleh non-Muslim

Pemikiran hukum yang berkaitan dengan keabsahan makanan yang dijual oleh orang non-Muslim, termuat dalam buku "kumpulan fatwa Majelis”.Fatwa tersebut menyatakan, apabila diketahui bahwa daging hewan tersebut disembelih oleh orang Islam dengan menggunakan syariat, serta tidak bercampur dengan benda yang haram maka hukumnya halal. Jika tidak diketahui tempat, siapa yang menyembelihnya, maka hukumnya haram karena diyakini telah bercampur dengan masakan barang haram lainnya.

${ }^{9}$ Komisi Farwa MUI: no 43 tentang Penyalah gunaan dan Pengolahan Ikan,diselenggarakan pada tanggal I8 bulan Desember 2012 


\section{Makanan dan Minuman Produk Barat Dalam Pandangan Ulama}

Kholishudin, Shelvyna Rikantasari

Perdagangan antar bangsa dan negara di zaman modern saat ini sudah menjadi bagian penting dan tidak terpisahkan dari perekonomian suatu negara.Bahkan penggalakan dan kemudahan diupayakan semudah mungkin untuk melakukan perdagangan.Sudah banyak pasar bebas di banyak tempat dan negara.Apalagi ditunjang kemudahan transportasi darat, laut, udara, dan kemudahan berkomunikasi diantara mereka.

Makanan dan minuman produk Barat saat ini telah marak beredar di Indonesia.Banyak produk Barat yang dapat didapatkan dengan mudah seperti di supermarket yang besar khususnya di Kota Surabaya.Produk-produk makanan dan minuman ini bermacam-macam seperti mie Samyang, ramen, udon, keju, coklat, makanan daging kaleng dsb serta minuman seperti coca-cola, Fanta dan minuman yang mengandung alkohol.Dengan keadaan demikian juga menimbulkan banyak permasalahan baru, diantaranya hukum barang-barang impor tersebut dalam tinjauan halal dan haramnya.

Jenis barang impor yang masuk ke dalam negara Indonesia dapat dikategorikan dalam dua kategori, yaitu kategori barang makanan, di dalamnya termasuk buah-buahan, sayur-sayuran, tepung, mie instan, daging-dagingan, minuman ringan $\mathrm{dsb}$, serta kategori barang non makanan, seperti barang elektronik dan yang lainnya. Dalam hal ini semua yang di impor dari negara muslim yang tidak melanggar syariat Islam sudah jelas hukumnya halal. Namun yang perlu mendapat penjelasan adalah barang yang di impor dari Negara-negara nonmuslim.Barang dalam kategori non makanan dan minuman sudah jelas hukumnya diperbolehkan, selama tidak digunakan dalam perkara yang salah dan menyelisihi syariat Islam.Sedangkan barang impor dari jenis makanan dapat dikategorikan lagi ke dalam kategori yang bukan sembelihan dan kategori yang butuh disembelih (daging).

Volume. 9/No. 2/Juli 202I Al-Iqtishod | II9 
Makanan dan Minuman ...

Makanan atau bahan makanan yang diimpor adakalanya barang yang alami, seperti buah-buahan, beras, gandum dsb.Adapun tentang jenis ini, sepakat bahwa para ulama menghalalkannya.Juga adakalanya merupakan hasil industri yang tidak berhubungan dengan agama non Islam, seperti roti, tepung dan sejenisnya.Hukumnya, jenis ini halal selama belum tercampur bagian dari hewan sembelihan orang yang diharamkan sembelihannya seperti kaum Musrik atau Majusi, contohnya keju.

Keju merupakan produk yang banyak dikonsumsi oleh kaum muslimin, khususnya di Indonesia, baik sebagai campuran roti atau yang lainnya.Ternyata bila melihat ke pasar atau supermarket, didapatkan keju-keju tersebut di impor dari luar negeri, khususnya Eropa dan Australia. Padahal dalam proses pembuatan keju selalu membutuhkan enzim Renin (infihah) yang diambil dari lambung anak sapi yang masih menyusui. Ada juga yang menyatakan dari anak sapi yang masih berusia tiga hari sampai sepekan.

Hukumnya tentu harus melihat kepada hewan yang diambil enzim reninya tersebut.Apabila enzim renin ini diambil dari hewan yang disembelih dengan menggunakan sembelihan sesuai syariat maka hukumnya halal.Namun masalahnya, bila berasal dari hewan yang tidak disembelih sesuai syariat, seperti dipotong dengan listrik atau dicekik dan sebagiannya, atau diimpor dari negara non ahlu kitab seperti, negara Majusi, Hindu, atau sembelihan orang kafir non ahlu kitab.Sembelihan mereka dalam pandangan syariat adalah bangkai. ${ }^{10}$

Dalam masalah ini terjadi perbedaan pendapat diantara para ulama bagi golongan yang membolehkan merujuk kepada pendapat Imam Abu Hanifah bila barang semula najis dan berubah menjadi tidak najis maka hukumnya tidak najis.. Sementara kelompok yang tidak membolehkan bersandar kepada pendapat Imam Malik dan Imam Shafíi yang mengatakan enzim adalah najis. Jadi tergantung pada hewan tersebut jika berasal dari daging hewan yang halal makan enzim renin

${ }^{10}$ Islamweb.net-al-ahkam almutaaliqah bi alatimah 2-7-2009.

I20| Al-Iqtishod Volume. 9/No. 2/Juli 202I 
hukumnya jadi halal termasuk makanan yang dicampur dengan bahan tersebut demikian juga sebaliknya bila berasal dari daging hewan yang haram maka hukumnya jadi haram seperti babi.

Pendapat yang membolehkan ini dikuatkan oleh oleh Ibnu Taimiyah dalam pernyataan beliau: "yang rajih, keju mereka (orang-orang Majusi) adalah halal dan enzim Renin dari bangkai dan susunya adalah suci. Alasannya, karena para sahabat ketika berhasil menaklukan negeri Irak memakan keju buatan orang Majusi dan ini masyhur di antara mereka.”

Inilah pendapat yang membolehkan dengan beberapa alasan sebagai berikut $:^{11}$

a. Enzim Renin tersebut suci walaupun dari bangkai, karena para sahabat ketika berhasil menaklukan negeri Irak memakan keju buatan orang Majusi dan ini masyhur di antara mereka. Apabila enzim tersebut najis, tentulah mereka tidak memakannya.

b. Enzim Renin dan susu yang digunakan untuk membuat keju bukan bangkai, karena sudah mengalami istihalah berubah dari wujud aslinya sehingga tidak tepat jika dianggap najis hanya keran enzim tersebut ada pada lambung hewan sembelihan orang yang tidak sah sembelihannya, sebab benda cair yang terkena najis tidak harus najis, kecuali bila ada perubahan salah satu sifatnya.

Dengan demikian, maka keju yang ada pada jaman dahulu dan sekarang hukumnya halal selama belum jelas keju tersebut mengandung hal-hal yang haram, seperti lemak babi atau sejenisnya.

Berikut ini adalah ulasan tentang makanan Impor berupa sembelihan atau daging.Permasalahan ini menjadi sangat penting, karena kaum muslimin dewasa ini sudah sangat membutuhkan daging impor. Hal ini dikarenakan, suplai daging yang menjadi kebutuhan masyarakat terkadang tidak dapat dipenuhi dari dalam negeri sendiri.m Dalam hal harga, terkadang daging impor juga lebih murah daripada daging lokal.Sehingga

"Islamweb.net.madhahib al ulama fi akli aljabn al masnu' biifihati almaitah, I6-3-202I2.

Volume. 9/No. 2/Juli 202I Al-Iqtishod| I2I 
Makanan dan Minuman ...

mennetahui hukum syariat seputar daging impor dari negara mereka ini sangat mendesak untuk dikaji lebih lanjut.

Daging impor produk barat ini dapat dikategorikan sebagai berikut : ${ }^{12}$

a. Daging impor produk barat berupa daging hewan laut, seperti ikan dan sejenisnya, maka hukumnya halal, karena hewan laut halal dimakan tanpa sembelihan syar'i sekalipun, baik yang menangkapnya muslim ataupun nonmuslim

b. Daging impor tersebut berupa daging yang diharamkan untuk dimakan, seperti daging babi, anjing, dan sejenisnya, maka ini jelas haram hukumnya.

c. Daging impor tersebut berupa daging hewan yang halal dimakan, seperti unta, sapi, kambing, unggas dan sejenisnya, maka ini perlu adanya perincian lagi

I. Bila diimpor dari Negara barat non ahlu kitab atau disembelih oleh orang non muslim dari Negara manapun hukumnya haram

2. Bila diimpor dari Negara non muslim ahlu kitab atau berasal dari sembelihan ahlu kitab, maka tidak lepas dar tiga keadaan $:^{13}$

- Yang diketahui jelas telah disembelih sesuai tata cara syariat, maka halal secara ijma berdasarkan keumuman dalil QS al Maidah [5] :5. Mereka melakukan tata cara menyembelih sebagaimana umat islam menyembelihnya hewan ternak mereka yaitu dengan memotong tenggorokan hewan.

- Yang diketahui tidak sembelih sesuai dengan tata cara syariat, hukumnya haram. Karena beberapa alasan :

a) Keumuman sembelihan ahlu kitab halal ini masih dikecualikan dengan sembelihan yang mereka halalkan namun diharamkan dalam syari” at Islam seperti daging babi, sehingga bisa jadi keumuman tersebut dikhususkan yang disembelih sesuai syari' at Islam.

${ }^{12}$ Islamweb.net.qararal-majami’ al-fiqhiyyah wa al-ifta fi dhabaih al-arubyyin.

${ }^{13}$ Muhammad Yusuf al-Qaradawi, Al Halal wa Al-Haram fi al-Islam (Surabaya: PT Bina Ilmu, I990), I66. 
b) Sembelihan mereka dengan cara dicekik masuk dalam al Munkhaniqah (hewan tercekik) dan yang mereka sembelih dengan cara dipukul masuk dalam al Mauqudzah yang telah Allah haramkan dalam firmanNya: "Diharamkan bagimu (memakan) bangkai, darah, daging babi, (daging hewan) yang disembelih atas nama selain Allah, yang tercekik, yang terpukul, yang jatuh, yang ditanduk, yang diterkam binatang buas, kecuali yang sempat kamu menyembelihnya, dan (diharamkan bagimu) yang disembelih untuk berhala. Dan (diharamkan juga) mengundi nasib dengan anak panah, (mengundi nasib dengan anak panah itu) adalah kefasikan.” (QS. al Maidah : 3)

c) Yang tidak diketahui keadaannya, sehingga tidak diketahui binatang tersebut disembelih dengan cara apa. Dalam masalah ini al Lajnah al Daimah lil Buhus Ilmiyah me-rajih-kan haramnya dengan alasan: ${ }^{14}$

I. Allah mengharamkan daging hewan yang mati tanpa disembelih sesuai sembelihan syar" $i$ dalam firman Allah: “ Diharamkan bagimu (memakan) bangkai, darah, daging babi, (daging hewan) yang disembelih atas nama selain Allah, yang tercekik, yang terpukul, yang jatuh, yang ditanduk, yang diterkam binatang buas, kecuali yang sempat kamu menyembelihnya.” (QS. al Maidah: 3) Sehingga yang belum pasti disembelih dengan sembelihan syar"i adalah haram.

2. Kaidah yang dikenal dalam agama Islam, "apabila berkumpul dalil yang melarang dengan dalil yang membolehkan, maka didahulukan yang melarangnya”. Daging ini berada diantara

\footnotetext{
${ }^{14}$ Khalid bin Muflih bin Abdillah Ali Hamid, Ikhtiyarat Ibn Baz al-Fiqhiyah wa Arauhu fi Qadaya Muasirah Juz 2 (Jeddah: Dar al-Fadilah, 2010), 1677.
}

Volume. 9/No. 2/Juli 202I A1-Iqtishod| 123 
anggapan disembelih dengan sembelihan yang diperbolehkan dengan yang tidak diperbolehkan. Sehingga didahulukan sisi pengharamannya.

3. Sebagian besar dari daging impor yang memenuhi pasar dunia sangat sulit dipastikan disembelih sesuai sembelihan syar'i dengan syarat-syaratnya.

4. Penyimpangan dan jauhnya manusia dari agamanya dan hukum-hukum agama telah merata di zaman ini. Ditambah tidak ada amanah dan kejujuran pada para eksportir, walaupun mereka mengklaim dalam tulisannya "disembelih sesuai syari" at". Padahal masih banyak ditemukan ayam yang diekspor (ke negeri Arab) yang masih utuh kepalanya tanpa sembelihan. Selain itu, tulisan tersebut juga terdapat pada ikan yang diimpor, padahal ikan tidak butuh disembelih.

\section{E. Simpulan}

Kehalalan meliputi bagaimana cara produk itu diperoleh, diproses, dan faktor lain. Sesuatu yang dapat merusak pikiran, tubuh, dan jiwa dikatagorikan dengan perkara haram. Halal dalam hal makanan tidak memuat bahan atau unsur haram atau sesuatu yang tidak diizinkan untuk dikonsumsi dan cara pengolahan yang sesuai syariat Islam. Halal adalah suatu tindakan yang diperbolehkan untuk dilakukan sesuai dengan syariat.Label halal dapat dicantumkan oleh suatu perusahaan jika perusahaan tersebut sudah memiliki sertifikat halal.

Sertifikat halal merupakan surat keterangan yang dikeluarkan oleh MUI Pusat atau Propinsi tentang halalnya suatu produk makanan, minuman, obat-obatan dan kosmetika yang diproduksi oleh suatu perusahaan setelah diteliti dan dinyatakan oleh LPPOM MUI.Dalam hal pemberian label makanan halal ini ada empat fatwa yang berkaitan dengan makanan. Semua fatwa itu adalah mengenai status hukum dari penyembelihan hewan 
dengan alat teknologi atau mesin, mengenai hewan yang dijual dalam keadaan sudah disembelih, daging yang diawetkan dan daging yang dijual oleh non muslim.

\section{F. Daftar Pustaka}

a. Buku

Al Hafidz, AW, Fiqh Kesehatan Jakarta: Amzah, 2007

Ali Hamid, Khalid bin Muflih bin Abdillah, Ikhtiyarat al-Shaykh bin Baz alFiqhiyah wa Arauhu fi Qadaya Muasirah, Riyad :Dar al-Fadilah ,2010.

Al-Qaradawy, Muhammad Yusuf.Al Halal wa al Haram fi al Islam, Surabaya PT Bina Ilmu 1990

Departemen Agama RI , Al Quran dan Tafsirnya jilid I (edisi yang disempurnakan cet, I: Jakarta Depag RI , 2004

Umar ,Hasbi. Nalar Fiqh Kontemporer, Ciputat: Gaung Persada , 2007

Ya'kub, Ali Mustafa. Kreteria Halal-Haram Pangan ,Obat dan Kosmetika menurut al-Quran dan Hadis, Jakarta: Pustaka Firdaus, 2010.

b. Buku berjilid

Syihah, M. Quraish, Tafsir al Misbah jilid IJakarta; Lentera Hati, 2002

Al Maraghi, Tafsir al-Maraghi Jilid 3Cet V. Kairo, Mustafa alBabi al-Halabi, 1974.

Al Zuhayli, Wahbah, al-Fiqh al-Islami wa Adillatu Juz 4. Lebanon: Dar al Fikr, 2008

Rida, Rasyid, Tafsir al-Manar Jilid 4. Mesir: Maktabah al-Qahirah, I380

Al Lajnah al-Daimah lil Buhus al-Ilmiyah, Fatawa al-Lajnah al-Daimah Juz 22 Bab alHudud wa al said. Jeddah: Dar al-Fadhilah. 2010

c. Artikel JurnalVersiCetak

Muslih. Perusahaan harus pahami syarat SJH jurnal halal no 9I XIV 20II Jakarta LP POM MUI

Volume. 9/No. 2/Juli 202I A1-Iqtishod| I25 
Makanan dan Minuman ...

Ratna, ratna. Persepsi label halal pada makanan impor berdasarkan factor pekerjaan konsumen di kindonesia

Yanggo, Huzaimah Tahido, Makanan dan minuman dalam perspektif hukum Islam jurnal Tahkim vol IX no. 2, Desember 2013.

I26| A1-Iqtishod Volume. 9/No. 2/Juli 202I 